\section{Alexander Muk}

is the assistant advertising professor of Texas State University-San Marcos, and has published research papers in Journal of Targeting, Measurement and Analysis for Marketing and Journal of International Advertising.

Keywords: mobile, coupons, America, Korea, Taiwan, perceptions

\section{Perceptions of mobile coupons: A cross-national study}

\author{
Alexander Muk
}

Received (in revised form): 21st November 2011

\begin{abstract}
This study investigates cross-national differences between young consumers' intentions to use mobile coupons and their attitudes towards SMS coupons. A survey was conducted for collecting data from the universities in the US, Korea and Taiwan. The convenience samples consisted of 171 American, 154 Korean and 198 Taiwanese students. The results reveal that young American consumers' acceptance of mobile coupons is influenced by perceived control and brand value. Young Korean and Taiwanese consumers' intentions to use mobile coupons are mainly affected by the economic value of the coupons. The convenience of mobile coupons allows international advertisers to distribute mobile coupons in Asian markets without the need for setting up an elaborate redemption system. In the US, opting into mobile marketing services should be less restrictive and easy to terminate. In Asia, issuing mobile coupons for group use is a tactic to get young Asian consumers to interact with the brand. Journal of Direct, Data and Digital Marketing Practice (2012) 13, 311-324. doi:10.1057/dddmp.2011.48
\end{abstract}

\section{Introduction}

The mobile phone is a new interactive medium that allows marketers to distribute mobile coupons to target consumers at desired times and locations. ${ }^{1}$ American fast food chains Burger King and McDonalds use Short Message Service (SMS) to distribute coupons to their consumers. In 2009, American consumers redeemed 10 million digital coupons. ${ }^{2}$

Coupons that are distributed through the print media have very little success in Asian markets because most Asian countries do not have well-established coupon distribution and redemption systems. In addition, Asian consumers are not accustomed to using coupons and are embarrassed to be seen using coupons in public. ${ }^{3}$ To promote coupon use, Asian marketers use mobile technologies for distribution. The direct channel makes mobile coupons easy to receive, convenient to use and less visible in the redemption process. As Ashworth et al. ${ }^{4}$ point out, consumers are more likely to use coupons when the redemption can be done in private.

Mobile phone penetration rates in Korea and Taiwan have reached 100 per cent. In the US, about 90 per cent of the population have cell phones. Redemption for mobile coupons is 15 times higher than print 


\section{Difficulty making MMS coupons mainstream}

coupons. ${ }^{2}$ And mobile coupons provide better-targeted strategies than print coupons can offer. Past research identifies uses and gratification, entertainment, interpersonal influences and convenience ${ }^{5,6}$ as factors that influence consumers' acceptance of mobile marketing. National characteristics and societal impact on accepting mobile coupons have yet to be understood as important factors. Little research has been conducted to investigate consumers' willingness to adopt mobile coupons across cultures. To fill this gap, this paper examines what factors would influence consumers to redeem mobile coupons, as well as their attitudes and motivations towards use. This research studies American, Korean and Taiwanese consumers because of their differences in social behaviours and cultural preferences.

\section{Literature review}

\section{Mobile coupons}

Mobile coupons can be distributed via the mobile phones or personal digital assistants. SMS, Multimedia Messaging Service (MMS) and mobile websites can be used for distributing mobile coupons to the consumers. SMS delivers mobile coupons in text format only and MMS allows images, sound and videos to be added to the mobile coupons. The mobile coupon is making inroads into the coupon market because of its low production cost and the high return on investment. ${ }^{7}$

The time-consuming process of clipping, organizing and redeeming print coupons influences the consumers' perceptions of using coupon. ${ }^{8}$ Mobile technologies, however, make mobile coupons more convenient to receive and easy to use. SMS delivers coupons in text code to the consumers' mobile phones by their request. To redeem the coupons, consumers have to show the text code stored in their phones at the point of purchase. This method is more effective because consumers choose to opt in to get the offers. MMS distributes coupons in the form of a two-dimensional bar code with a logo or an image attached. And mobile coupon applications are available for smartphone users to download MMS coupons. Redemption of MMS coupons is done by scanning the bar code through a reading device at the point of purchase. This method has less support in the retail outlets because of the incurred cost of installing the reading devices in the cash registers. The least widespread couponing method is to place coupons on mobile websites. ${ }^{9}$ In terms of usage, SMS is the most used mobile application in advertising and almost 65 per cent of the mobile phone users text every day. ${ }^{10}$ Therefore, this study only focuses on examining consumers' acceptance of SMS coupons.

\section{Research framework and hypotheses}

The conceptual framework is based on the modified Technology Acceptance Model (TAM) developed by Dickinger and Kleijnen ${ }^{11}$ for studying acceptance of mobile coupons. Originally, the TAM is derived from the theoretical foundations of the Theory of Reasoned Action (TRA). ${ }^{12}$ According to the TRA, consumers' attitudes shape 
behavioural intentions. Essentially, the theory suggests that the formation of specific intentions to act may result in actual behaviours. The TRA also posits that intentions to act are determined by social influence or subjective norms. The original TAM model uses perceived usefulness and perceived ease of use variables to study technology users' intentions to adopt an innovation. Dickinger and Kleijnen ${ }^{11}$ modified the TAM model by adding three more constructs - attitude, perceived control and social influence - to study consumers' intentions to use mobile coupons (see Figure 1). Their ${ }^{11}$ findings reveal that all constructs are positively related except the relationship between the redemption effort and the attitude variables, which is negative.

\section{Beliefs about SMS coupons}

The beliefs that consumers have about mobile coupons are stored cognitively. These cognitions help determine a consumer's initial attitude towards using mobile coupons. The perceived costs and benefits of using coupons are the utilitarian benefits that consumers see in using coupons. These are perceived values of coupons to the consumers and may serve as cognitive antecedents of attitudes towards mobile coupons. In the context of SMS coupon, perceived usefulness is the economic benefit that consumers receive from redeeming the coupons. As the value of the coupon increases, consumers' attitudes towards mobile coupons become more positive. ${ }^{13}$ The time and effort involved in collecting and redeeming print coupons hinder the usage. However, receiving and redeeming the mobile coupons are not entirely effortless. It still requires consumers to learn the cognitive process of requesting an SMS coupon and storing it in the cell phone. ${ }^{11}$ The effort involved in redeeming a mobile coupon is equivalent to the ease of use variable in the TAM. Consumers are sensitive to the negative impression of being cheap, which is associated with using coupons. ${ }^{4}$ The negative social impression of using coupons can be changed if peers or friends judge the mobile coupons as worthwhile to get and useful. In this instance, consumers are more inclined to conform to their peers' opinions. Past research on print and electronic coupon usage suggests that attitudes and social influence significantly affect consumers' intentions to use them. ${ }^{14,15}$

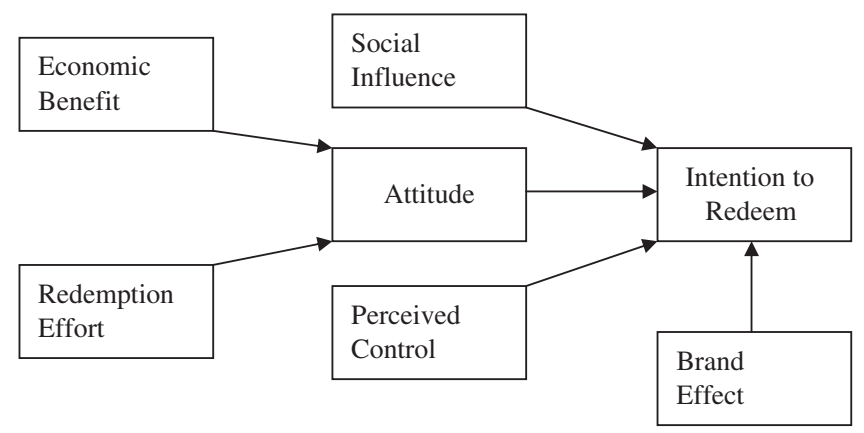

Figure 1: Conceptual model 


\author{
Mobile marketing \\ intrudes on consumer \\ privacy
}

\section{Attitudes towards mobile coupons}

Past cross-national research consistently shows that Americans' consumption behaviours are linked to attitudes and Asians' consumption behaviours are affected by social norms. ${ }^{16}$ Shimp and Kavas $^{14}$ argue that personal attitudes and subjective norms are important determinants of consumers' intentions to use coupons because the effects of attitudes and subjective norms on actual behaviours are mediated via behavioural intentions. Attitudes and personality are internal factors that influence consumers' acceptance of an innovation. ${ }^{17,18}$ Consumers' attitudes towards mobile coupons are developed through their cognitive learning of mobile marketing. Mobile marketing research shows that American consumers strongly value their privacy rights. They see mobile marketing as an intrusion on their privacy and have no interest in receiving it. ${ }^{11}$ The fear of mobile spam also makes American consumers shun SMS advertising. In contrast, Asian consumers' attitudes towards SMS advertising are positive, ${ }^{19}$ and Asian marketers have already used SMS to distribute mobile coupons to the consumers. Studies show that Taiwanese and Korean consumers are well accustomed to accepting mobile advertising via their mobile phones. ${ }^{20,21}$ The concern of privacy invasion and the perceptions of mobile coupons are the important determinants of American consumers' attitudes towards mobile coupons.

\section{H1: American consumers will have a more negative attitude towards mobile coupons than Korean and Taiwanese consumers.}

\section{Societal influence}

In Asia, societal factors drive the adoption of mobile advertising. ${ }^{19}$ Two social factors may influence Asian consumers' attitudes towards using mobile coupons. One is the fear of embarrassment when using the coupons in public. ${ }^{3,22}$ The other social factor is the subjective norms, which refer to the consumer's perception of the social or peer pressure to accept or not accept mobile coupons. In Taiwan, peer pressure influences consumers' attitudes towards using coupons. Past research consistently shows that social factors have significant positive effects on Taiwanese consumers' acceptance of mobile advertising. ${ }^{23,24}$ However, subjective norms have no effects on American and Korean consumers' intentions to opt in to mobile marketing activities. ${ }^{25}$ Thus, the second and third hypotheses are developed based on societal influences on Taiwanese consumers.

H2: Taiwanese consumers will exhibit a stronger positive relationship between subjective norms and intentions to redeem mobile coupons than American and Korean consumers.

H3: Social influence will be the strongest predictor of Taiwanese consumers' intentions to accept mobile coupons. 


\section{Perceived control}

SMS coupons are delivered via the permission-based model that consumers have to opt in to receive the SMS coupons. The opt-in and -out mechanism is an important customer relationship tool that offers the customers greater control over the acquisition and use of their personal information by the mobile marketers. ${ }^{26}$ In addition, the opt-in program allows customers to control when and where they want to receive the mobile coupons. The Theory of Planned Behavior (TPB), an extension of TRA, theorizes that Perceived Behavioral Control (PCB) is a determinant of behavioural intentions. The PCB suggests that, consumers will act when they believe they have the skills, resources and opportunities to perform the required behaviour and controlling the outcome of it. ${ }^{15}$ Using the TPB to study consumers' intentions to use mobile coupons, Dickinger and Kleijnen ${ }^{11}$ found that consumers are more likely to use mobile coupons if they can control the outcome of the communication process. Online shopping behaviour and e-coupon usage studies also show that online shopping sites with clear privacy policy reduce American consumers' concerns over privacy intrusion. ${ }^{15,27}$ The opt-in model also enhances American consumers' positive intentions to accept SMS coupons. ${ }^{23}$ In this instance, perceived control would be an important determinant in predicting American consumers' acceptance of mobile coupons.

\section{H4: Perceived control will be the strongest predictor of American consumers' intentions to accept mobile coupons.}

\section{Korea leads in mobile marketing}

\section{Coupon use}

Coupon usage is influenced by the ease or difficulty of redeeming a coupon. ${ }^{28}$ The Korean coupon market started in the late 1990s. Since then, it has achieved a 30 per cent growth. The money-saving aspect of coupons motivates the price-sensitive Korean consumers to use them. Using mobile technologies to distribute marketing activities makes Korea a leading country in mobile advertising. ${ }^{20}$ Young Korean consumers embrace mobile coupons and even forward them to friends as gifts. Bauer et al. ${ }^{29}$ suggest that avid users of mobile communications will have less difficulty to use related mobile communication services. In contrast, coupon values have no influence on the Taiwanese and American consumers' purchase decision. ${ }^{4,22}$ The following hypotheses are formulated on the basis of the aforementioned discussion.

H5: Economic values will be the strongest predictor of Korean consumers' intentions to redeem mobile coupons.

H6: Korean consumers will exhibit a stronger intention to redeem SMS coupons than American and Taiwanese consumers. 


\section{Brand effect}

Coupons distributed under a brand name have added values, and positive perceptions of a brand also help raise brand awareness. In general, consumers trust a reputable brand name more because of the quality assurance. American consumers use reputable brands' coupons because familiar brand names reinforce their purchase decision. ${ }^{30}$ However, loyalty may impede coupon use when consumers do not have the coupon for their favourite brands. ${ }^{31}$ Thus, brand-conscious American consumers are more likely to redeem coupons of their favourite brands. In addition, reputable brand names provide the consumers with confidence to adopt an innovative product. ${ }^{32}$ Asian consumers do not consciously add value to their favourite brands. ${ }^{17}$ Their brand loyalty is not related to the perceptions of the individual brand's values itself but rather to the value of belonging to the group of consumers who use the brand. ${ }^{33}$ In this instance, individual brand names are less likely to influence Asian consumers' purchase decision. Rettie et al. $^{34}$ argue that brands using SMS advertising can stimulate consumer response and significantly affect their attitudes towards the brands. Thus, it is reasonable to expect a strong brand effect on the American consumers.

H7: The brand value would have a stronger effect on American consumers' intentions to use mobile coupons than their Asian counterparts.

\section{Research methodology}

\section{Sampling}

Convenience samples of university students under 25 years of age were selected as sampling units because they represent the largest segment of SMS users and fit the characteristics of the heavy users of mobile technologies. ${ }^{21,25}$ Past research consistently shows that young people around the world are highly interested in mobile advertising and coupons. ${ }^{19,35}$ The samples consisted of 171 American, 154 Korean and 198 Taiwanese students.

\section{Measurement and scaling}

Following Brislin's ${ }^{36}$ translation process, the English questionnaire was back-translated into Korean and Chinese. The items measuring coupon value, perceived control, redemption effort, attitude towards mobile coupon and social influence were adapted and modified from Muk's ${ }^{23}$ research. The brand effect scales were adapted from Sichtmann's ${ }^{32}$ study. All the items were measured on seven-point Likert scales ranging from 'strongly disagree' (1) to 'strongly agree' (7). Attitude was measured on three seven-point semantic differential scales. One single dependent variable (intention to redeem SMS coupons) was measured on a seven-point scale ranging from 'extremely unlikely' (1) to 'extremely likely' (7). Some questionnaire items were coded in reverse to restrict respondents' acquiescence bias (see Table 1). 
Table 1: Rotated factor matrix

\begin{tabular}{|c|c|c|c|c|c|c|}
\hline \multirow[t]{2}{*}{ Item } & \multicolumn{6}{|c|}{ Factors } \\
\hline & 1 & 2 & 3 & 4 & 5 & 6 \\
\hline \multicolumn{7}{|l|}{ Control } \\
\hline Easy to opt in & 0.724 & - & - & - & - & - \\
\hline Privacy protection & 0.784 & - & - & - & - & - \\
\hline Easy to opt out & 0.800 & - & - & - & - & - \\
\hline $\begin{array}{l}\text { Control receiving } \\
\text { coupons }\end{array}$ & 0.785 & - & - & - & - & - \\
\hline \multicolumn{7}{|l|}{ Coupon value } \\
\hline Saving money & - & 0.785 & - & - & - & - \\
\hline Convenience & - & 0.724 & - & - & - & - \\
\hline Economic gain & - & 0.827 & - & - & - & - \\
\hline Shopping incentives & - & 0.815 & - & - & - & - \\
\hline \multicolumn{7}{|l|}{ Social influence } \\
\hline Close friends & - & - & 0.890 & - & - & - \\
\hline Family members & - & - & 0.840 & - & - & - \\
\hline Peers & - & - & 0.848 & - & - & - \\
\hline \multicolumn{7}{|l|}{ Brand effect } \\
\hline Brand image & - & - & - & 0.677 & - & - \\
\hline Brand is reliable & - & - & - & 0.753 & - & - \\
\hline Brand trust & - & - & - & 0.705 & - & - \\
\hline Reference for purchase & - & - & - & 0.724 & - & - \\
\hline \multicolumn{7}{|l|}{ Redemption Effort } \\
\hline Easy to redeem & - & - & - & - & 0.772 & - \\
\hline $\begin{array}{l}\text { Complicated to get } \\
\text { coupons }\end{array}$ & - & - & - & - & 0.477 & - \\
\hline $\begin{array}{l}\text { Require little mental } \\
\text { effort }\end{array}$ & - & - & - & - & 0.816 & - \\
\hline Storing is easy & - & - & - & - & 0.737 & - \\
\hline \multicolumn{7}{|l|}{ Attitude } \\
\hline $\mathrm{Bad} / \mathrm{Good}$ & - & - & - & - & - & 0.732 \\
\hline Wise/Foolish & - & - & - & - & - & 0.814 \\
\hline Harmful/Beneficial & - & - & - & - & - & 0.666 \\
\hline Loadings $^{a}$ & 13.6 & 13.7 & 11.1 & 10.13 & 9.19 & 8.6 \\
\hline
\end{tabular}

Note: Dashes indicate coefficients less than 0.5 .

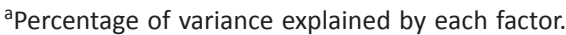

\section{Data analysis}

\section{Reliability and validity measures}

The coefficient alpha for each construct showed adequate convergence ranging from 0.78 to 0.90 , with the exception of redemption effort, which showed a lower value of 0.62 . Using factor analysis with varimax rotation to validate the constructs also resulted in a six-factor solution with eigenvalues greater than 1.0 (see Table 1).

\section{Test of hypotheses}

Correlation coefficient was used to examine the strength of relationships between attitude, economic benefit and redemption effort variables. The correlation results of the combined data set of the three samples showed significant results, $r(523)=0.415, p<0.001$, for the 
Table 2: Regression analysis for variables predicting intentions (combined data set $N=523$ )

\begin{tabular}{lccl}
\hline Variable & B & SE & $\beta$ \\
\hline Attitude & 0.198 & 0.018 & $0.424^{* * *}$ \\
Social influence & 0.015 & 0.004 & $0.103^{* *}$ \\
Perceived control & 0.044 & 0.010 & $0.177^{* * *}$ \\
Brand effect & 0.021 & 0.011 & 0.070 \\
Country & 0.004 & 0.074 & 0.037 \\
\hline
\end{tabular}

Note: $\mathrm{R}^{2}=0.57$.

$* * * p<0.001 ; * * p<0.01$.

relationship between attitude and economic benefit and $r(523)=0.30$, $p<0.001$ for the relationship between attitude and redemption effort. These results indicated that the belief variables were found to predict the corresponding direct measures of attitude.

The same data set was used to test the relationships between attitude, social influence, perceived control, brand effect and intention. A dummy variable representing the three countries was included as a predictor in the model. The $F$-test results were significant $\left(R^{2}=0.57\right.$, $F(3,519)=61.1, p>0.001)$, and showed that all the relationships were positively related to intention. Table 2 presents the regression results.

ANOVA was run to test $\mathrm{H} 1$. The significant results $(F(2,520)=9.5$, $p>0.001$ ) supported H1, which stated that Americans would have a more negative attitude towards mobile coupon than their Korean and Taiwanese counterparts. The post hoc comparisons using Tukey HSD also showed significant differences in the mean scores of American $(M=-1.42)$, Korean $(M=-0.183)$ and Taiwanese $(M=-0.773)$.

The regression analyses used to test the second hypotheses consisted of three independent models, one for each data set with the intention variable regressing on attitude, economic benefit, brand effect, perceived control and social influence variables (see Tables 3, 4 and 5 for the regression results).

The $F$-tests for the three models were significant, US data $\left(R^{2}=0.27\right.$, $F(2,168)=15.5, p>0.001)$, Korean data $\left(R^{2}=0.39, F(2,151)=22.9\right.$, $p>0.001)$ and Taiwanese data $\left(R^{2}=0.31, F(2,195)=21.8, p>0.001\right)$. The second hypothesis posited that Taiwanese consumers would exhibit a stronger positive relationship between social influence and intention to redeem mobile coupons than American and Korean consumers. The Beta weight of the social influence variable in the Taiwanese data was significant $(\beta=0.127, p<0.05)$, whereas the Beta weights of the US data $(\beta=0.047)$ and Korean data $(\beta=0.060)$ were not significant. Therefore, $\mathrm{H} 2$ was supported.

Stepwise regression analyses were employed to test Hypotheses 3, 4 and 5. Table 6 represents the stepwise regression results.

$\mathrm{H} 3$ posited that coupon value would be the strongest predictor of Korean consumers' intentions to redeem mobile coupons. Controlling for perceived control, brand effect, redemption effort and social influence, coupon value predicted a significant proportion of variance 
Table 3: Regression analysis of intentions (US $N=171$ )

\begin{tabular}{lccl}
\hline Variable & B & SE & $\beta$ \\
\hline Attitude & 0.142 & 0.033 & $0.339^{* * *}$ \\
Social influence & 0.009 & 0.012 & 0.04 \\
Perceived control & 0.046 & 0.018 & $0.205^{* *}$ \\
Brand effect & 0.036 & 0.019 & $0.128^{*}$ \\
\hline
\end{tabular}

Note: $\mathrm{R}^{2}=0.273$

$* * *<<0.001 ; * * p<0.01 ; * p<0.05$.

Table 4: Regression analysis of intentions (Korea $N=154$ )

\begin{tabular}{lccl}
\hline Variable & B & SE & $\beta$ \\
\hline Attitude & 0.225 & 0.038 & $0.425^{* * *}$ \\
Social influence & 0.007 & 0.007 & 0.060 \\
Perceived control & 0.086 & 0.002 & $0.290^{* * *}$ \\
Brand effect & 0.018 & 0.019 & 0.062 \\
\hline
\end{tabular}

Note: $\mathrm{R}^{2}=0.392$

$* * * p<0.001$.

Table 5: Regression analysis of intentions (Taiwan $N=198$ )

\begin{tabular}{lccl}
\hline Variable & B & SE & $\beta$ \\
\hline Attitude & 0.223 & 0.031 & $0.461^{* * *}$ \\
Social influence & 0.015 & 0.007 & $0.127^{*}$ \\
Perceived control & 0.014 & 0.016 & 0.161 \\
Brand effect & 0.007 & 0.019 & 0.022 \\
\hline
\end{tabular}

Note: $\mathrm{R}^{2}=0.312$.

$* * * p<0.001 ; * p<0.05$.

Table 6: Stepwise regression analysis for variables predicting intentions

\begin{tabular}{llllll}
\hline Country & Predictors & $\beta$ & $R^{2}$ & $\Delta R^{2}$ & \multicolumn{1}{c}{$t$} \\
\hline \multirow{2}{*}{ Korea } & Coupon value & 0.323 & 0.251 & 0.251 & $3.46^{* * *}$ \\
& Control & 0.276 & 0.299 & 0.048 & $2.94^{* *}$ \\
\multirow{4}{*}{ US } & Control & 0.265 & 0.166 & 0.166 & $3.09^{* *}$ \\
& Coupon value & 0.203 & 0.196 & 0.030 & $2.37^{*}$ \\
& Brand effect & 0.145 & 0.216 & 0.020 & $2.09^{*}$ \\
Taiwan & Coupon value & 0.262 & 0.083 & 0.083 & $3.90^{* * *}$ \\
& Social influence & 0.229 & 0.135 & 0.052 & $3.40^{* * *}$ \\
\hline
\end{tabular}

$* * * p<0.001 ; * * p<0.01 ; * p<0.05$

in intention $\left(R^{2}\right.$ Change $\left.=0.25, F(1,152)=50.0, p<0.001\right)$. H3 was supported.

The significant results also showed that perceived control was the strongest predictor of American consumers' intentions to accept SMS coupons $\left(R^{2}\right.$ Change $\left.=0.166, F(1,169)=33.7, p<0.001\right)$. H4 was also supported. 
H5 posited that social influence would be the strongest predictor of Taiwanese consumers' intentions to accept mobile coupons. The regression results, however, revealed that social influence variable accounted for only 5 per cent of the total variance for Taiwanese consumers. H5 was not supported.

The sixth hypothesis predicted that the intention to redeem mobile coupons was stronger for the Korean consumers than for the American and Taiwanese consumers. The ANOVA results were significant $(F(2,512)=9.4, p>0.05)$ but the post hoc comparisons showed that there was no significant difference in the means between Korean $(M=2.7)$ and Taiwanese $(M=2.4)$ consumers. In this instance, H6 was partially supported.

As shown in Tables 3, 4 and 5, only the brand effect variable in the American data set was significant $(\beta=0.128, p<0.05)$. These results supported $\mathrm{H} 7$, which stated that brand value would have a stronger effect on American consumers' intentions to use mobile coupons.

\section{Discussion}

This study provides an initial evidence that a nation's societal characteristics do influence its people's receptiveness to mobile coupons. The findings show that the economic benefits of mobile coupons are significantly related to the consumers' attitudes towards using mobile coupons. The positive attitude-intention relationship suggests that the likeability factor increases consumers' intentions to use mobile coupons. Peer pressure does affect Taiwanese respondents' intentions to use mobile coupons but has no effect on the American and Korean respondents. The constant exposure to mobile coupons and the experience with using them may explain why social pressure has no influence on the technology-savvy young Koreans' intentions to use mobile coupons. They may rely more on their personal experience with mobile coupons than on influence by their relevant others. Perceived control also affects their intention because of the recent increase in mobile spam in the Korean mobile market. ${ }^{20}$ American respondents' negative attitudes towards mobile coupons are related to their fear of privacy intrusion. This supports the theory of psychological reactance that consumers would react negatively if they believe their freedom is being restricted. ${ }^{37}$ In this instance, the commanding aspect of the opt-in model assures consumers that they can control the outcome of the communication process. ${ }^{11}$ In general, young American consumers are sceptical about advertising. ${ }^{38}$ Among the three sample groups, young Koreans exhibit more favourable attitudes towards mobile coupons.

The value of the brand and the monetary incentives of mobile coupons have a positive effect on brand-conscious Americans' intentions to use mobile coupons. Korean and Taiwanese consumers' motives to redeem mobile coupons are mainly driven by the value offered. As Raghubir ${ }^{13}$ suggests, the perceived monetary values from redeeming the coupons enhance consumers' favourable attitudes towards the coupons. 


\section{Mobile coupons suitable for leading brands}

\section{Managerial implications}

The negative attitudes that American consumers have towards mobile coupons are developed on the basis of privacy concern and the fear of mobile spam. The opt-in model gives them the assurance of controlling the communication process and weakening their fear of privacy invasion. In this case, American advertisers should make the opt-in and-out mechanism easy to use. Offering privacy protection can forge a trustful relationship with the mobile coupon users. The mobile coupons are more appropriate for the leading brands than for the lesser known brands. As the attribution theory suggests, products marketed under reputable brand names are more likely to gain consumers' acceptance because of the perceived trust and quality in the brands. The trust strengthens the connection between attitudes and behaviours. ${ }^{37}$

The social effects on the Taiwanese consumers indicate that important referents' opinions and group behaviours cannot be ignored in markets where consumers are group oriented. Taiwanese mobile advertisers should create a group distribution application that allows group members to share the coupons. They should be given more incentives to redeem the coupons together as a group, such as the buy two get one free type of deal. Asian consumers are driven more by value than by brand loyalty. Korean and Taiwanese mobile advertisers should capitalize on the mobility and ubiquity of wireless technologies by using proximity marketing to alert their customers about the special offers available in nearby stores. The offers should be positioned as an exclusive personalized service for loyal customers. Instead of making the coupons a short-term call to action type of promotion, advertisers should set a longer expiration date to reward loyalty. This adds value to the coupon as it can be easily stored in the cell phone. International advertisers should take advantage of the low visibility of using mobile coupons to encourage face-saving Asian consumers to accept mobile coupons and use the opt-in model to build relationship with them.

\section{Limitations, future research and future perspectives}

The convenience sample used in this study limits its generalizability. As age and education were controlled for this study, future researchers should consider using a random sampling of different demographic segments. Discount size and coupon formats should be included to examine the effects of perceived values in mobile coupons. Thus, a better explication of mobile coupon usage can be formed by analysing the similarities and differences between demographic segments. This study used a self-reported questionnaire survey based on intention measures, which has its limitation. Future research should consider employing behavioural measures because the approach may provide a better understanding of consumers' motives for using mobile coupons. Future research may also investigate the other forms of mobile coupons. Coupons distributed by MMS with colour and graphics may have a more aesthetic appeal than the plain text coupons. Findings in this research could have been skewed by the similar cultural patterns of Korea and Taiwan; therefore, future 


\section{Outlook of NFC in mobile coupons}

research may choose to replicate this study by including other countries.

The outlook of mobile coupons may rest on the near-field communication (NFC) technology. ${ }^{39}$ NFC is a short-range wireless technology that allows mobile devices exchange data in a very short distance. The close proximity of the communication exchange between two NFC devices eliminates the possibility of the signal being intercepted, which is an inherent security other mobile technologies cannot offer. To receive a coupon, the consumer simply waves or taps his NFC-equipped smartphone against an NFC-enabled advertising sign or poster. No further action - texting the advertiser or visiting a mobile website - is required to complete the process. In this instance, no personal information about the consumer is collected. NFC-equipped smartphone is the future of the mobile wallet. A variety of functions, from receiving the mobile coupon to redeeming it for payment, can be performed just by tapping the phone against a reader. NFC coupons simplify the redemption process without the permission model. This reduces the privacy concerns consumers have with mobile coupons and prompts them to make impulse purchases.

\section{Conclusion}

The findings of this study reveal that American and Korean consumers' decisions on redeeming SMS coupons are solely based on their own judgement, whereas Taiwanese consumers' intentions to act are influenced by social norms as well as by attitudinal factors. The results also illustrate the relative importance of coupon values in affecting consumers' perceptions of mobile coupons. The propositions presented in this study reveal that there are national differences between the young American, Korean and Taiwanese consumers in adopting mobile coupons. In general, the unfavourable attitudes American consumers have towards mobile coupons are related to their perceived risk of privacy invasion. Monetary incentives are the main driver for Asian consumers to use mobile coupons.

\section{References}

1. Peters, C., Amato, C. H. and Hollenbeck, C. R. (2007) 'An exploratory investigation of consumers' perceptions of wireless advertising', Journal of Advertising, Vol. 36, No. 4, pp. 129-145.

2. Wortham, J. (2009) 'Coupons you don't clip, sent to your cellphone', The New York Times, available at http://www.nytimes.com/2009/08/29/technology/29coupon.html.

3. Kashani, K. and Quelch, J. (1990) 'Can sales promotion go global?' Business Horizons, Vol. 33, No. 3, pp. 37-43.

4. Ashworth, L., Darke, P.R. and Schaller, M. (2005) 'No one wants to look cheap: Trade-offs between social disincentives and the Economic and psychological incentives to redeem coupons', Journal of Consumer Psychology Research, Vol. 15, pp. 295-306.

5. Scharl, A., Dickinger, A. and Murphy, J. (2004) 'Diffusion and success factors of mobile marketing', Electronic Commerce Research and Applications, Vol. 4, pp. 159-173.

6. Muk, A. and Babin, J.B. (2006) 'US consumers' adoption-nonadoption of mobile SMS Advertising', International Journal of Mobile Marketing, Vol. 1, No. 1, pp. 21-29. 
7. Shankar, V., Venkatesh, A., Hofacker, C. and Naik, P. (2010) 'Mobile marketing in the retail environment: Current insights and future research avenues', Journal of Interactive Marketing, Vol. 24, pp. 111-120.

8. Chakraborty, G. and Cole, C. (1991) 'Coupon characteristics and brand choice', Psychology \& Marketing, Vol. 8, pp. 145-159.

9. Reedy, S. (2009) 'Mobile coupon go mainstream', Telephony, July/August, p. 30.

10. Phau, I. and Teah, M. (2009) 'Young consumers' motives for using SMS and perceptions towards SMS Advertising', Direct Marketing: An International Journal, Vol. 3, No. 2, pp. $97-108$.

11. Dickinger, A. and Kleijnen, M. (2008) 'Coupons going wireless: Determinants of consumer intentions to redeem mobile coupons', Journal of Interactive Marketing, Vol. 22, No. 3, pp. 23-39.

12. Ajzen, I. and Fishbein, M. (1980) Understanding Attitudes and Predicting Social Behavior, Prentice Hall, Englewood Cliffs, NJ.

13. Raghubir, P. (2004) 'Coupons in context: Discounting prices or decreasing profits?' Journal of Retailing, Vol. 80, pp. 1-12.

14. Shimp, T. A. and Kavas, A. (1984) 'The theory of reasoned action applied to coupon usage', Journal of Consumer Research, Vol. 11(December), pp. 795-809.

15. Kang, H., Hahn, M., Fortin, D.R., Hyun, Y.J. and Eom, Y. (2006) 'Effects of perceived behavioral control on the consumer usage intention of e-coupons', Psychology \& Marketing, Vol. 23, pp. 841-864.

16. Bagozzi, R., Wong, N., Abe, S. and Bergami, M. (2000) 'Cultural and situational contingencies and the theory of reasoned action: Application to fast food restaurant consumption', Journal of Consumer Psychology, Vol. 9, No. 2, pp. 97-106.

17. De Mooij, M. (2010) Global Marketing and Advertising: Understanding Cultural Paradoxes, (2nd edn.) Sage, Thousand Oaks, CA.

18. Triandis, H. (2004) 'The many dimensions of culture', Academy of Management Executive, Vol. 8, No. 1, pp. 88-93.

19. Fowler, G. (2005) 'Asia's mobileads; US firms study what flies on hot medium and why: And how to try it at home', The Wall Street Journal, 25 April, p. B1.

20. ABI Research. (2007) 'Mobile marketing and advertising in Japan and South Korea', available at http://www.abiresearch.com/products/market_research/MOCA.

21. Tsang, M., Ho, S.C. and Liang, T.P. (2004) 'Consumer attitudes toward mobile advertising: An empirical study', International Journal of Electronic Commerce, Vol. 8, No. 3, pp. 65-78.

22. Huff, L. and Alden, D. (1988) 'An investigation of consumer response to dales promotions in developing Markets: A three-country analysis', Journal of Advertising Research, Vol. 38, No. 3, pp. $47-56$

23. Muk, A. (2007) 'Cultural influences on adoption of SMS advertising: A study of American and Taiwanese consumers', Journal of Targeting, Measurement and Analysis for Marketing, Vol. 16, No. 10, pp. 39-47.

24. Yang, K. (2007) 'Exploring factors affecting consumer intention to use mobile marketing in Taiwan', Journal of International Consumer Marketing, Vol. 20, No. 1, pp. 33-49.

25. Muk, A. (2007) 'Consumers' intentions to opt in to SMS advertising', International Journal of Advertising, Vol. 26, No. 2, pp. 177-198.

26. Barwise, P. and Strong, C. (2002) 'Permission-based mobile advertising', Journal of Interactive Marketing, Vol. 16, pp. 14-24.

27. Ha, H.Y. (2004) 'Factor influencing consumer perceptions of brand trust online', The Journal of Product and Brand Management, Vol. 13, No. 4/5, pp. 329-342.

28. Bagozzi, R.P., Baumgartner, H. and Yi, Y. (1992) 'State versus action orientation and the theory of reasoned action: Application to coupon usage', Journal of Consumer Research, Vol. 18, pp. 505-518.

29. Bauer, H., Barnes, S., Reichardt, T. and Neumann, M. (2005) 'Driving consumer acceptance of mobile marketing: A theoretical framework and empirical study', Journal of Electronic Commerce, Vol. 6, No. 3, pp. 184-192. 
30. Bawa, K. and Shoemaker, R. (1987) 'The effects of a direct mail coupon on brand choice behavior', Journal of Marketing Research, Vol. 24, No. 4, pp. 370-376.

31. Mittal, B. (1994) 'An integrated framework for relating diverse consumer characteristics to supermarket coupon redemption', Journal of Marketing Research, Vol. 31, No. 4, pp. 533-544.

32. Sichtmann, C. (2007) 'An analysis of antecedents and consequences of trust in a corporate brand', European Journal of Marketing, Vol. 41, No. 9/10, pp. 999-1015.

33. Malai, V. and Speece, M. (2005) 'Cultural impact on the relationship among perceived quality, brand name value, and customer loyalty', Journal of International Consumer Marketing, Vol. 17, No. 4, pp. 7-39.

34. Rettie, R., Grandcolas, U. and Deakins, B. (2005) 'Text message advertising, response rates and branding effect', Journal of Targeting, Measurement and Analysis for Marketing, Vol. 13, No. 4, pp. 304-312.

35. Reitsma, R. (2009) 'The Data Digest: Interest in mobile coupons', available at http://blogs. forrester.com/category/mobile_coupons.

36. Brislin, R.W. (1986) 'The wording and translation of research instruments', in Lonner, W. J. and Berry, J. W. (eds) Field Methods in Cross-cultural Research, Sage, Beverly Hills, CA, pp. $137-164$.

37. Mowen, J. and Minor, M. (2001) Consumer Behavior: A Framework, Prentice-Hall, Upper Saddle River, NJ.

38. Zanton, E. (1981) 'Public attitudes toward advertising', in Hunt, K. (ed) Advertising in a New Age, Proceedings of the Annual Conference of the American Academy of Advertising, Brigham Young University Press, Provost, UT, pp. 141-146.

39. Ortiz Jr., S. (2006) 'Is near-field communication close to success?' Computer, March, pp. 18-20. 